\title{
Predisposed to Volunteer? \\ Personality Traits and \\ Different Forms of \\ Volunteering
}

Nonprofit and Voluntary Sector Quarterly 2019, Vol. 48(6) III9-1142

(C) The Author(s) 2019

Article reuse guidelines: sagepub.com/journals-permissions DOI: $10.1177 / 0899764019848484$ journals.sagepub.com/home/nvs

@SAGE

\section{Kathrin Ackermann 1,2 iD}

\begin{abstract}
In this article, we evaluate the psychological basis of different forms of volunteering. To date, our knowledge about the relationship between personality and volunteering as an important facet of the social fabric is limited. Applying the Five-Factor Model of Personality (Big Five), we scrutinize this relationship in a comprehensive manner. We consider formal and informal volunteering as well as online volunteering as a new form of social participation. Empirically, we analyze a representative population sample of Switzerland using logistic regression models. We find that extraversion is the most consistent driver of volunteering. The effects of the remaining traits differ across the forms of volunteering. Additional analyses indicate that situational factors may moderate these relationships.
\end{abstract}

\section{Keywords}

personality, Big Five, volunteering, online volunteering, moderating effects

\section{Introduction}

Volunteering is an essential element of public life in modern societies. Measured in economic terms, the value of voluntary work in Organisation for Economic Co-operation and Development (OECD) countries amounts, on average, to 1.9\% of the GDP (OECD, 2015). The importance of volunteering for social cohesion even exceeds its economic value. Against this backdrop, it is relevant for actors in politics and civil society to know about the factors that motivate people to voluntarily contribute to a common good. To

'Heidelberg University, Germany

${ }^{2}$ Goethe University Frankfurt, Germany (Associate Member)

\section{Corresponding Author:}

Kathrin Ackermann, Institute of Political Science, Heidelberg University, 691 17 Heidelberg, Germany.

Email: kathrin.ackermann@ipw.uni-heidelberg.de 
date, volunteering is mostly explained using sociodemographic, socioeconomic, and contextual factors (Wilson, 2012). However, this approach cannot fully reveal why some people volunteer and others do not. Even though education, for instance, is a good predictor of volunteering (Gesthuizen \& Scheepers, 2012), there are people with relatively low levels of education who volunteer and highly educated people who do not. Similarly, direct democracy as an institutional setting is supposed to promote volunteering (Stadelmann-Steffen \& Freitag, 2010). Yet, not everyone living in a direct democratic context carries out voluntary work. How can this existing variation between people who find themselves in identical social contexts or socioeconomic positions be explained? One possible explanation may lie in an individual's psychological dispositions. Hence, we investigate in this article if and how personality traits are related to different forms of volunteering.

The importance of psychological factors, such as dispositions, values, or motives, for volunteering is uncontested (Smith, 1994; Wilson, 2012). As Musick and Wilson (2008) put it, this research strand assumes that "we cannot understand human behavior entirely from the 'outside' by looking at people's objective attributes or their social position; we have to know something about what is going on in their minds" (p. 37). Dispositions in the sense of personality traits are key psychological factors for human behavior and have been empirically linked to volunteering before. Using the well-established Five-Factor Model ("Big Five") to grasp psychological dispositions, we build on this existing work and extend it in two respects. First, we examine the role of psychological dispositions for three different forms of volunteering: formal, informal, and online volunteering. Existing studies mostly focus on one specific form of volunteering: formal volunteering within associations (Bekkers, 2005; Carlo, Okun, Knight, \& de Guzman, 2005; Dinesen, Nørgaard, \& Klemmensen, 2014), informal volunteering (Finkelstein \& Brannick, 2007), or volunteering for specific purposes (Finkelstein, Penner, \& Brannick, 2005; Omoto, Snyder, \& Hackett, 2010; Weinschenk, 2013). ${ }^{1}$ A comprehensive and nuanced analysis, however, allows us to disentangle whether personality traits are differentially related to different forms of volunteering. By considering online volunteering, our study accounts for current developments in social participation and provides insights into the foundations of this rather new phenomenon (Ackermann \& Manatschal, 2018). Second, we investigate whether traits can be activated by situational factors that are beneficial for volunteering (see also Bekkers, 2005). In other words, are individuals more likely to act according to their psychological dispositions if they have more time or if social networks encourage them to do so? Altogether, our study will be informative for societal and political actors. For actors in the nonprofit sector, it provides evidence of the types of persons they can attract as volunteers and may inspire them to adapt their offers for other types of persons. Political actors can learn which circumstances are favorable for individuals to act upon their dispositions.

Empirically, we test our theoretical expectations using data from the Swiss Volunteering Survey 2014. Logistic regression models show that extraversion is a consistent driver of volunteering. For the remaining personality traits, we find different dynamics for the three forms of volunteering. For instance, openness to experience is 
positively related to online volunteering, whereas agreeableness fosters informal volunteering, and emotional stability is a prerequisite of formal volunteering. Situational factors, such as time constraints or social networks, somewhat moderate the link between personality and volunteering.

\section{Defining the Concepts: Volunteering and Personality Traits}

According to Wilson (2000) "volunteering means any activity in which time is given freely to benefit another person, group or organization" (p. 215). ${ }^{2}$ Research typically distinguishes between formal and informal volunteering (Carson, 1999; Lee \& Brudney, 2012). If voluntary activities are carried out within the organizational structures of a club or association, it is called formal volunteering. Coaching a nonprofessional football team that is part of a club would be an example of formal volunteering. If volunteering takes place outside of these formal structures, it is described as informal volunteering. Helping an elderly neighbor to shop for groceries is an example of informal volunteering. Thus, formal volunteering is characterized by a higher degree of commitment to an organization and less flexibility compared with informal volunteering. Because the Internet affects all spheres of modern life, online volunteering complements these two conventional forms of volunteering. Online volunteering, or virtual volunteering, can be understood as a "type of civic engagement where the volunteers perform their tasks using the Internet either from their home or other offsite locations" (Mukherjee, 2011, p. 253). Faceto-face contact with others is not necessary for online volunteering. Nevertheless, it may be embedded in the formal structures of a club, but it might also be carried out individually. Examples of online volunteering could include contributing to Wikipedia, developing nonprofit tutorials for YouTube, or administering the website of a club. Compared with offline volunteering, online volunteering is more flexible regarding space, time, and topic (Amichai-Hamburger, 2008). For instance, volunteers are not restricted to local activities but may take part in global activities. Beyond the degree of flexibility, anonymity is the second major difference between online and offline voluntary work. While offline volunteering necessitates face-toface interaction and communication in most cases, online volunteering is often characterized by a higher degree of anonymity (Amichai-Hamburger, 2008).

The main goal of this article is to examine how the three different forms of volunteering relate to individual differences in psychological dispositions. As attentive observers of our social surroundings, we realize that individuals are characterized by differences in psychological dispositions that shape their behavior and attitudes in everyday situations (McCrae \& Costa, 2008). We conceptualize these dispositions as personality traits. Within trait theory, personality traits are considered to be the core component of an individual's personality. They structure a person's values, attitudes, and behavioral patterns (McCrae \& Costa, 2008; Mondak, 2010). The Five-Factor Model ("Big Five") has established itself as the standard within personality psychology for empirically capturing personality traits. It is based on lexical analyses, that is, 
the extraction of words characterizing people, which are deep seated in our everyday language and set down in lexicons (John, Naumann, \& Soto, 2008). Analyses have shown that the extracted adjectives describe five superordinate personality traits: openness to experience, conscientiousness, extraversion, agreeableness, and emotional stability. Recent social science research demonstrates the importance of these traits for social and especially political behavior and political attitudes (for an overview, see Gerber, Huber, Doherty, \& Dowling, 2011). The Big Five personality traits are correlated not only with ideological orientations and political engagement but also with political and social trust (see, for example, Freitag \& Ackermann, 2016; Freitag \& Bauer, 2016; Jost, Nosek, \& Gosling, 2008; Mondak, 2010).

\section{Theoretical Considerations on Personality Traits and Volunteering}

Essentially, we expect that personality traits relate to volunteering as a form of civic engagement. We argue that the relationships will differ across the forms of volunteering. To begin with, the trait openness to experience describes how keen a person is to new ideas, new experiences, and intellectual stimuli. Open people are considered open-minded, critical, nonconforming, and curious; they appreciate innovation and are able to reconsider their values systems (McCrae \& Costa, 2008; Mondak, 2010). For a person scoring high on openness, voluntary work offers the opportunity to make new experiences, meet new people, and encounter new ideas (Bekkers, 2005; Carlo et al., 2005; Dinesen et al., 2014). Online volunteering shall be particularly attractive to open persons (Quintelier \& Theocharis, 2013; Russo \& Amnå, 2016), because they can find flexible and nearly unlimited options to volunteer in interesting and challenging projects on the Internet. Online volunteering gives open-minded persons the opportunity to engage with new topics and forms of volunteering well beyond traditional voluntary work in an association or in the neighborhood.

A person scoring high on extraversion is characterized as being sociable, friendly, talkative, outgoing, and active. Volunteering is a perfect opportunity for extraverts to get in contact with others and to strive toward a common goal with them (Bekkers, 2005; Carlo et al., 2005; Dinesen et al., 2014; Okun, Pugliese, \& Rook, 2007; Omoto et al., 2010; Weinschenk, 2013). Due to their larger social networks, people scoring high on extraversion may also be more likely to be asked to volunteer. We argue that extraverts are especially likely to volunteer offline, both formally and informally. As voluntary work is an opportunity to meet with others, they will favor face-to-face encounters in real-world settings over the anonymity of the Internet. Although some studies indicate that extraverts are more likely to use social media (Amichai-Hamburger \& Vinitzky, 2010; Correa, Hinsley, \& de Zúñiga, 2010) and the Internet in general (Mark \& Ganzach, 2014), extraverts do not use it as a substitute for real-world encounters. They are more likely to use it for informational reasons or leisure than for social purposes (Amiel \& Sargent, 2004; Hamburger \& Ben-Artzi, 2000; Orchard \& Fullwood, 2010). In contrast, the Internet is the perfect setting for their counterparts, introverts, to express themselves under the shelter of anonymity (Amichai-Hamburger, 2008; Amichai-Hamburger, 
Wainapel, \& Fox, 2002; Quintelier \& Theocharis, 2013). Therefore, introverts are expected to have a higher probability to volunteer online than extraverts.

Agreeableness describes how people behave in relationships with others. A person scoring high on agreeableness is characterized as being trustful, cooperative, considerate, compassionate, caring, and thoughtful (McCrae \& Costa, 2008; Mondak, 2010). It resembles what Finkelstein and colleagues (2005; Finkelstein \& Brannick, 2007) describe as prosocial personality orientation. From a theoretical perspective, we, therefore, expect agreeable persons to have a higher propensity to volunteer as an act of benevolence. Thus, agreeableness should particularly foster informal volunteering because it is often related to caring for and helping others. Because conflictive situations involving the strategies, organization, or goals of a club are likely to occur in formal volunteering structures, we expect this type of engagement to not appeal to agreeable persons. Furthermore, we suppose that less agreeable persons prefer the anonymity of online volunteering compared with agreeable ones (Russo \& Amnå, 2016).

A person's score on the emotional stability scale quantifies their level of resistance to stress, resilience, and emotional control. A high degree of emotional stability indicates that a person is relaxed, can handle stress well, stays calm in tense situations, and does not worry a lot (McCrae \& Costa, 2008; Mondak, 2010). We argue that these characteristics are good preconditions for volunteering (Bekkers, 2005; Musick \& Wilson, 2008; Omoto et al., 2010). They are particularly important for formal volunteers, who might have to serve on a club's committee, debate with others about organizational issues, or represent the association in public. Emotionally stable persons can better handle difficult situations, in which volunteers find themselves from time to time, than their counterparts. Persons scoring low on emotional stability might be more likely to volunteer online. They are in general more likely to use the Internet, especially as a substitute for social contacts in the real world (Amichai-Hamburger et al., 2002; Amiel \& Sargent, 2004; Correa et al., 2010; Orchard \& Fullwood, 2010).

Finally, conscientiousness describes to what extent a person needs structure and hierarchy and complies to rules as well as how orderly, dutiful, efficient, disciplined, and hardworking a person is (McCrae \& Costa, 2008; Mondak, 2010). On one hand, conscientiousness may promote volunteering if it is seen as a citizenship norm (Dinesen et al., 2014). On the other hand, conscientious persons are described as efficient and might, therefore, avoid voluntary work, which has no immediate personal payoffs. Bekkers (2005) and Weinschenk (2013) find empirical support for this latter argument. As conscientious persons are also known to hold conservative values and attitudes, we expect them to volunteer in a traditional and conservative way, if they volunteer at all (Quintelier \& Theocharis, 2013; Russo \& Amnå, 2016). Thus, we hypothesize a negative relationship between conscientiousness and online volunteering.

\section{Data, Method, and Measurement}

To empirically test our arguments, we use data from the most recent Swiss Volunteering Survey, which was conducted between September and December 2014. ${ }^{3}$ The sample 
is randomly drawn from registry data of the Swiss Federal Statistical Office. The survey oversamples inhabitants of small cantons, young adults, as well as immigrants. Respondents were contacted via mail and could decide to answer the questionnaire online (computer-assisted web interview [CAWI]) or over the phone (computer-assisted telephone interview [CATI]). In total, 5,721 respondents were interviewed; the total response rate amounts to $20.2 \%$. Overall, the respondents are representative of the Swiss population regarding important sociodemographic and socioeconomic characteristics (Reimann, 2015). Online volunteering is only measured for respondents who answered via CAWI and those who indicated that they use the Internet during the telephone interview. To empirically assess the relationships between personality traits and different forms of volunteering, we estimate separate logistic regression models with clustered standard errors that account for contextual dependencies within the cantons.

Three dichotomous variables are the outcome variables of this study. One outcome variable measures formal volunteering by asking about voluntary work in a club or association. The second outcome variable captures informal volunteering as voluntary work performed not as part of a club or association and outside of the own household. To grasp online volunteering, respondents were given a list of online volunteering activities and asked whether they take part in any of these activities. A dichotomous variable measuring online volunteering is constructed based on this question. Our main explanatory variables - the Big Five personality traits - are measured using the Big Five Inventory-Short Form (BFI-S; Gerlitz \& Schupp, 2005). This short scale is based on the larger Big Five Inventory (BFI) Scale and comprises of 15 statements. Respondents were asked for a self-assessment about the extent to which the described characteristics apply to them on an 11-point scale. By means of an exploratory factor analysis, we show that the factor structure is reflected in our data (see Table OA1 in the online appendix). Finally, to operationalize the five traits, we followed the common approach in this field of research and built additive indices based on the solution of the factor analysis.

The primary interest of this study is to elicit the relationship between personality traits and different forms of volunteering. Therefore, it is essential to control for potentially confounding factors that may be related to both the explanatory and outcome variables and might bias the estimates of this relationship as a result (Jaccard \& Jacoby, 2009). Personality psychology shows that traits are partially based on genetics and only slightly change over the life span (Mondak, 2010). Thus, relatively few sociodemographic factors, such as sex, age, and educational level, are suspected to affect personality and the decision to volunteer. Our analysis controls for these variables. Because existing research indicates that the relationship between age and volunteering is nonlinear (Wilson, 2000), we also control for the quadratic term of age. Table A1 in the appendix presents an overview and further details on the operationalization of the concepts as well as some descriptive statistics. Table OA2 in the online appendix shows a correlation matrix of all variables included in the analyses. 


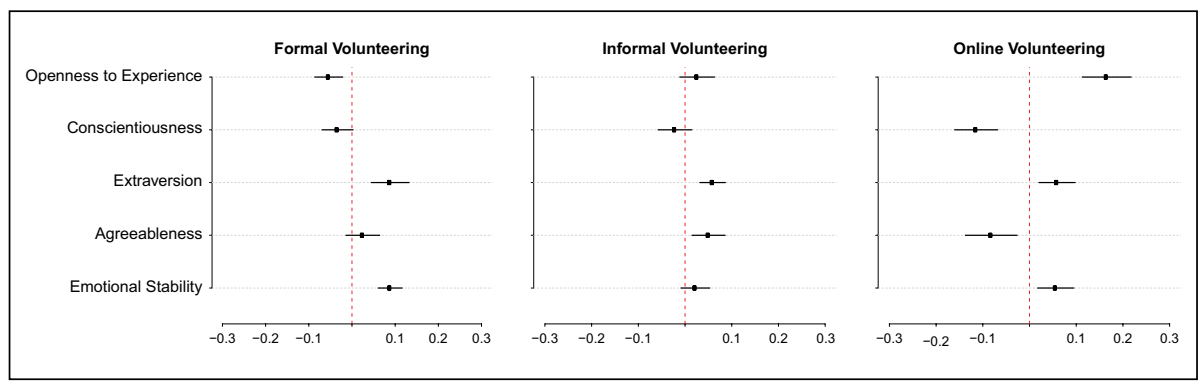

Figure I. The Big Five personality traits and volunteering in Switzerland (logistic regression models).

Note. Coefficient plot based on Models MI, M2, and M3 in Table A2 in the appendix. Dots illustrate regression coefficients; horizontal lines illustrate $95 \%$ confidence intervals.

\section{Empirical Findings}

How do personality traits relate to volunteering? First and foremost, we observe that personality traits are relevant in shaping volunteering in Switzerland (see Figure 1 and Table A2 in the appendix for the full regression results). Extraversion is a driving force behind volunteering and positively linked to all three forms considered in this study. This finding is in line with the existing literature (Bekkers, 2005; Dinesen et al., 2014; Musick \& Wilson, 2008; Omoto et al., 2010; Weinschenk, 2013). All else being equal, the propensity of a very extraverted person to volunteer formally or informally is more than 15 percentage points higher than the propensity of a very introverted one (see Figures 2 and 3). For online volunteering, this difference between extraverts and introverts is about half as big, yet the relationship is still significant (see Figure 4). ${ }^{4}$ Especially with regard to formal and informal volunteering, this result is perfectly in line with our theoretical expectations and with the findings in previous studies (Bekkers, 2005; Carlo et al., 2005; Dinesen et al., 2014; Okun et al., 2007; Omoto et al., 2010; Weinschenk, 2013). Extraverts are outgoing and sociable; they appreciate the opportunity to meet people and work together with others. Moreover, extraverts are more likely to be asked to volunteer due to their larger social networks. Concerning online volunteering, our findings do not confirm the hypothesis that introverts prefer the anonymity of the Internet for volunteering. Although the correlation is smaller, extraverts still are more likely to volunteer online than introverts.

For the remaining four traits, we observe differential dynamics depending on the form of volunteering. Being emotionally stable increases the likelihood of formal and online volunteering. If all other variables are held constant, the propensity of a very emotionally stable person to formally volunteer is about 18 percentage points higher than the propensity of a very emotionally unstable one. Thus, a high level of stress resistance seems to be an important precondition for volunteering in formal settings such as clubs or associations. This result corresponds to former findings in the literature (Omoto et al., 2010). Additional analyses indicate that emotionally stable 


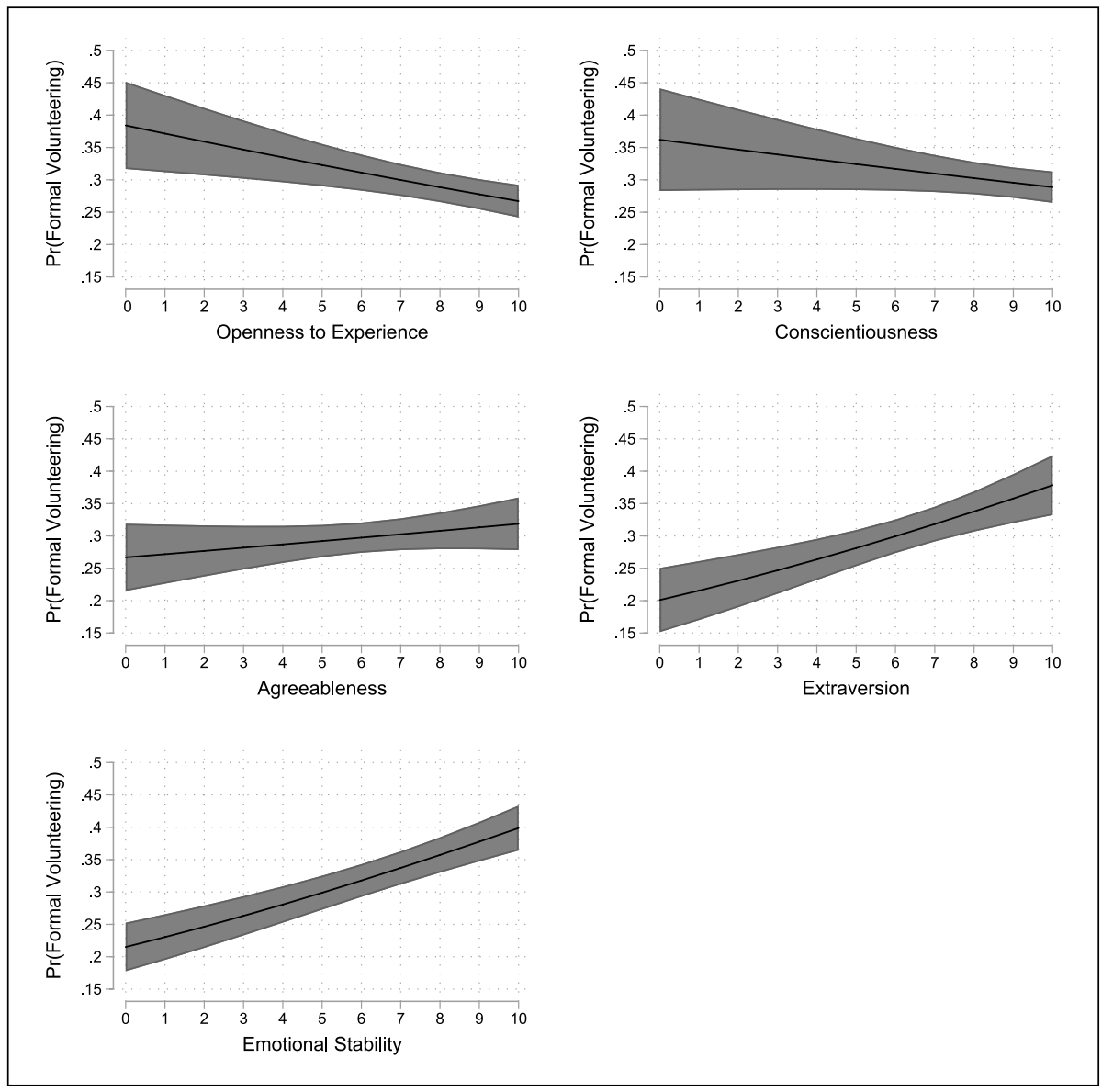

Figure 2. Predicted probabilities for formal volunteering across personality traits.

Note. Predicted probabilities calculated based on Model MI in Table A2 in the appendix (sex = female, education $=$ secondary, all other variables fixed to their means).

volunteers are also more likely to volunteer for multiple organizations (see Table A3 in the appendix). In contrast, emotionally unstable individuals do not differ from stable ones when it comes to helping others outside of formal structures (informal volunteering). For online volunteering, the difference between emotionally stable and unstable individuals is about 8 percentage points.

The personality trait agreeableness fosters informal volunteering as a way of helping and caring for others and is in line with existing research (Finkelstein \& Brannick, 2007). An agreeable person is about 12 percentage points more likely to informally volunteer than an individual scoring low on this trait. Agreeableness is not related to formal volunteering, which supports some former findings (Finkelstein et al., 2005) and contradicts others (Carlo et al., 2005). In accordance with our expectation, people 


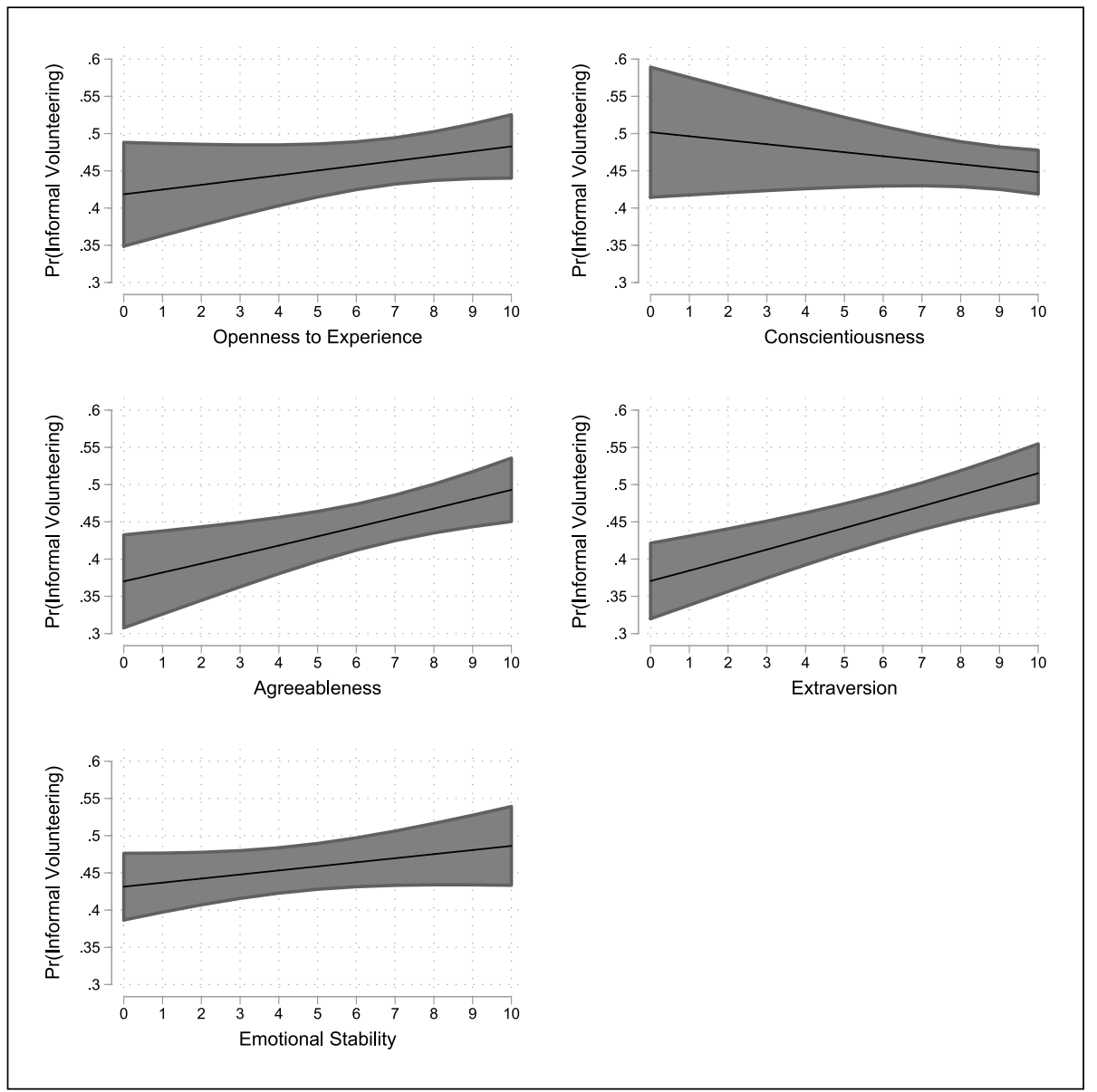

Figure 3. Predicted probabilities for informal volunteering across personality traits.

Note. Predicted probabilities calculated based on Model M2 in Table A2 in the appendix (sex = female, education $=$ secondary, all other variables fixed to their means).

scoring low on agreeableness are indeed more likely to volunteer in the anonymous online arena. All other things being equal, the difference in the predicted probability for online volunteering between a less agreeable and a very agreeable person is about 12 percentage points.

Openness to experience significantly increases an individual's propensity to volunteer online and decreases the likelihood of formal volunteering. In substantial terms, a very open-minded person is about 10 percentage points less likely than a close-minded person to volunteer in a club or association (all other variables hold constant). This runs contrary to the findings of Dinesen et al. (2014), who report a positive relationship with active membership in churches and unions. Openness to 


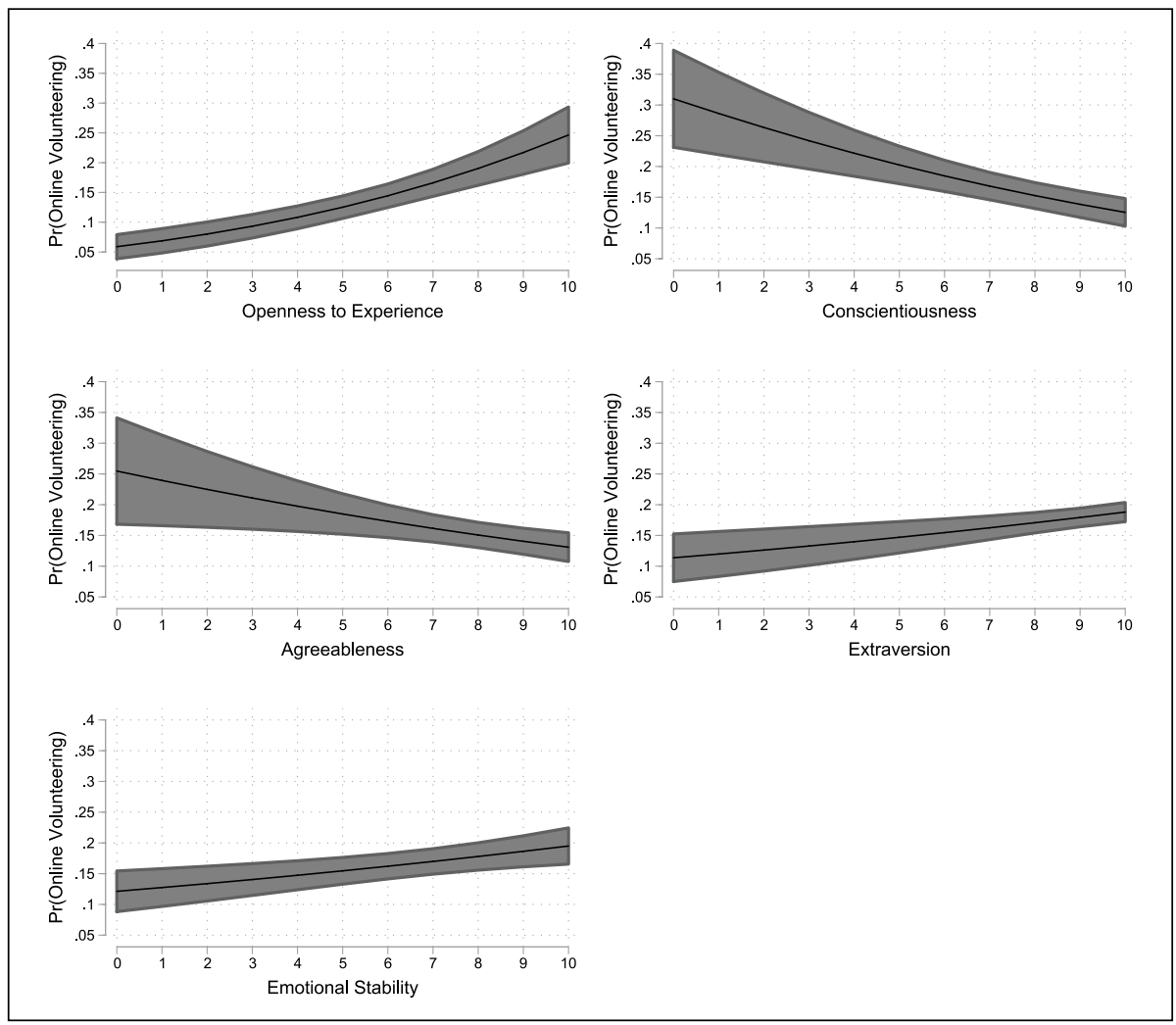

Figure 4. Predicted probabilities for online volunteering across personality traits.

Note. Predicted probabilities calculated based on Model M3 in Table A2 in the appendix (sex = female, education $=$ secondary, all other variables fixed to their means).

experience is not related to informal volunteering in our study. Meanwhile, an openminded person is about 20 percentage points more likely to volunteer online. This result meets our theoretical expectations and confirms the findings about online political participation (Quintelier \& Theocharis, 2013; Russo \& Amnå, 2016). Open people find new ideas and stimuli and can try new ways to contribute to the common good on the Internet. The conventional structures of clubs and associations are less appealing to them. However, if open-minded persons find their way to clubs and associations, the intensity of their engagement is higher compared with close-minded persons as measured by their weekly hours of engagement (see additional analyses in Table A3 in the appendix).

Finally, conscientiousness hampers participation in online volunteering. Compared with their less conscientious counterparts, persons scoring high on conscientiousness are about 18 percentage points less likely to volunteer online. Conscientiousness has been found to correlate with conservative views and values (Jost et al., 2008), which 


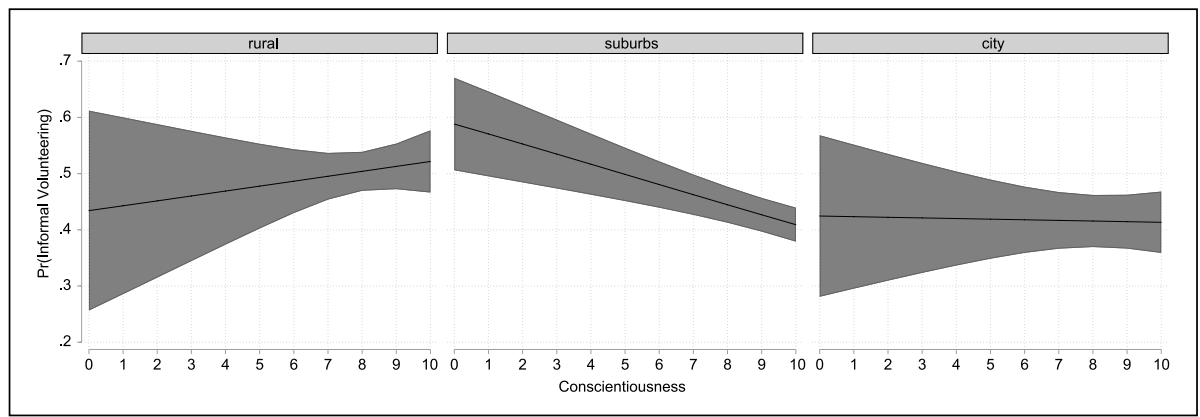

Figure 5. Predicted probabilities for informal volunteering across conscientiousness and type of residence.

Note. Predicted probabilities calculated based on Model M7.2 in Table A4 in the appendix (sex = female, education $=$ secondary, all other variables fixed to their means).

may explain the result for online volunteering. Our finding that conscientiousness is not related to formal or informal volunteering has been documented in previous studies (Carlo et al., 2005). Weinschenk (2013) even finds a negative correlation with political volunteering. Additional analyses on the intensity of volunteering show that if conscientious individuals volunteer in clubs and associations, then they devote more time to volunteering than less conscientious volunteers (see Table A3 in the appendix).

\section{The Moderating Role of Situational Factors}

In an additional and exploratory step of our analysis, we test whether situational factors can activate the effects of personality traits. Behavior is affected by both, longstanding psychological dispositions and situational circumstances (Musick \& Wilson, 2008). These two factors will exert their influence on an individual both independently and interactively (Funder, 2008). Thus, we believe that the link between personality traits and volunteering may depend on situational circumstances (see also Bekkers, 2005). We identify two situational factors that could be particularly relevant for volunteering, the embeddedness in social networks and time constraints (Wilson, 2012). If a person is embedded in tight social networks, it is more likely that she or he will be asked to volunteer. Moreover, such networks might exert social pressure to engage in volunteering. Given that conscientious individuals try to adhere to social norms and duties, we expect that they will be more likely to volunteer if they are embedded in social networks. Time constraints, however, might hamper social participation. We argue that this is especially the case for agreeable persons. Although they are generally expected to behave in a prosocial way and engage in volunteering (Musick \& Wilson, 2008), they might prioritize their family and close surroundings if they do not have much time.

We empirically examine these conditional relationships (Tables A4 and A5 in the appendix), and Figures 5 to 7 illustrate those interaction effects that 


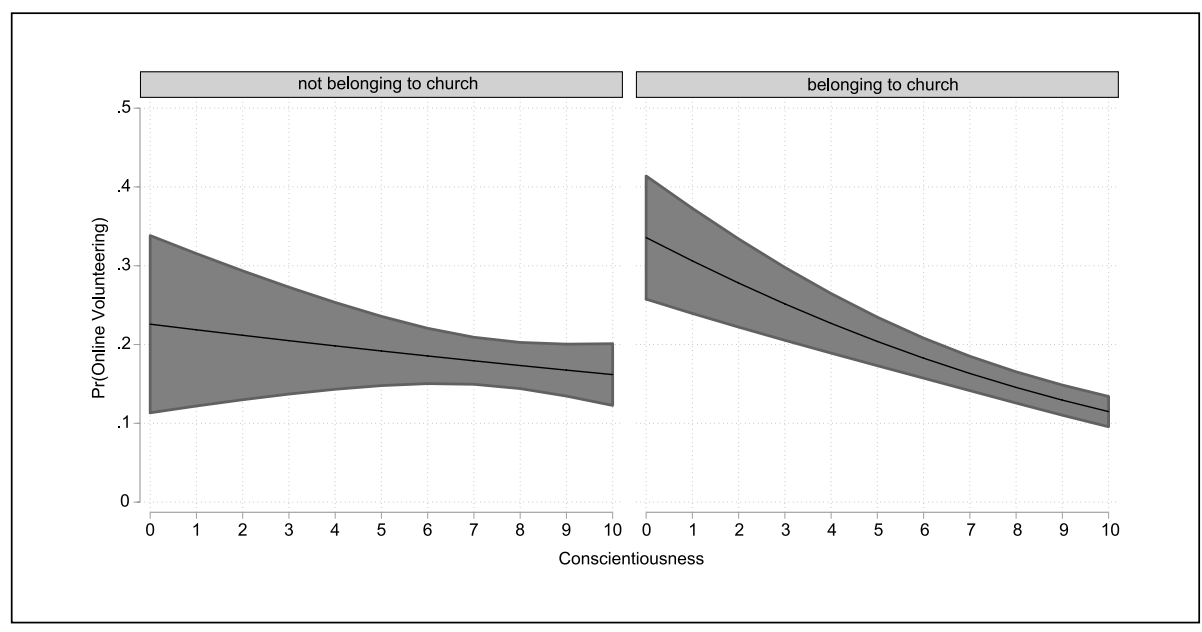

Figure 6. Predicted probabilities for online volunteering across conscientiousness and church membership.

Note. Predicted probabilities calculated based on Model M8.3 in Table A4 in the appendix (sex $=$ female, education $=$ secondary, all other variables fixed to their means).

are significant. Regarding the role of social network indicators for the effects of conscientiousness, Figure 5 shows that conscientious individuals living in the suburbs are less likely to informally volunteer than less conscientious ones. We assume that conscientious individuals become active if they perceive voluntary work as a duty or if they are directly asked and want to adhere to the norms in their context. These mechanisms of social integration seem to be absent for conscientious inhabitants of the suburbs. Commuting to work probably increases their focus on professional life and reduces time for social life in the community, especially for informal work that often requires flexibility and spontaneity. Moreover, Figure 6 illustrates that being a conscientious member of church is negatively linked to online volunteering. An ad hoc explanation for this negative interaction could be that the combination of high conscientiousness and church membership characterizes either conservative or elderly people. If they volunteer, they probably choose conventional and, most likely, church-related forms of volunteering instead of online volunteering. In conclusion, we fail to identify contexts that activate conscientiousness for volunteering, but we find evidence for contexts that deactivate this trait. The empirical results meet our expectations regarding agreeableness. Figure 7 indicates that agreeableness is positively related to informal volunteering for persons working part-time. If an agreeable person works parttime, she or he has enough time to take care of others outside of her or his own household. This result emphasizes that a prosocial personality orientation may not alone suffice for volunteering. For an agreeable person to become active, the situational context conditions need to facilitate volunteering. 


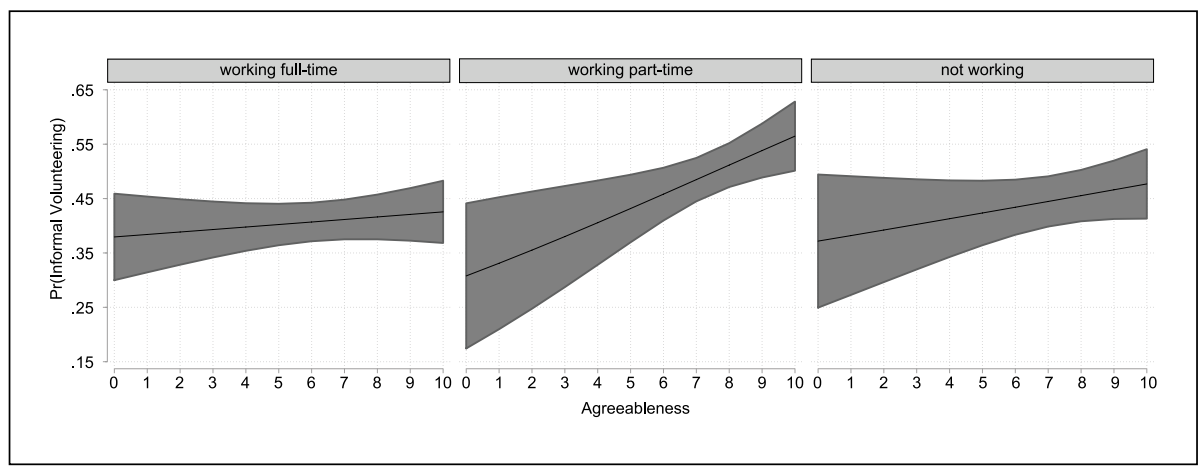

Figure 7. Predicted probabilities for informal volunteering across agreeableness and level of employment.

Note. Predicted probabilities calculated based on Model MI0.2 in Table A5 in the appendix $(\operatorname{sex}=$ female, education $=$ secondary, all other variables fixed to their means).

\section{Conclusion}

This article examines the relationship between personality traits and different forms of volunteering. In addition to the traditional forms of volunteering in clubs (formal volunteering) or helping people in the neighborhood (informal volunteering), we also consider online volunteering. Thus, we draw an encompassing picture of the psychological foundations of volunteering. In addition, we examine whether situational factors activate certain traits and enable individuals to behave according to their psychological dispositions. We apply the Five-Factor Model to capture personality and use the representative sample of the Swiss Volunteering Survey 2014 to empirically test our theoretical expectations. First and foremost, we find that extraversion is the most consistent driving force behind volunteering. Although extraversion is positively related to all three forms of volunteering, the remaining traits show different dynamics across the forms of volunteering. Openness to experience is, for instance, positively related to online volunteering. Agreeableness fosters informal volunteering and hampers online volunteering. Emotional stability is a strong prerequisite of formal volunteering and - to a lesser extent-of online volunteering. Conscientiousness is negatively related to online volunteering. Situational factors, such as time constraints or social networks, somewhat moderate the link between personality and volunteering. The relationship between conscientiousness and online volunteering is negatively moderated by church membership, whereas living in suburban areas decreases the effect of conscientiousness on informal volunteering. The link between agreeableness and informal volunteering is positively moderated by working part-time.

Our study attempts to illustrate the bigger picture of psychological dispositions and volunteering considering an encompassing model of personality and different forms of volunteering. For the very first time, we can include online volunteering 
in such a study. The results not only are relevant from a scientific perspective but also could be useful for voluntary associations and actors in politics and civil society for approaching current challenges in volunteering. It provides them with information about what stimuli attract which personality type when it comes to voluntary work. Knowing that open persons prefer volunteering on the Internet because they can participate in flexible and innovative ways, for instance, might force traditional real-world associations to think about how to cater new experiences to these people. Project-based engagement that is not tied to conventional membership and incorporates volunteers in the project's development might appeal to open-minded persons, for example. Associations could also consider opportunities for offering open-minded persons a combination of online and offline volunteering, for example, by using online crowdfunding for fundraising. Given that open-minded persons show a high intensity of volunteering if they decide to become active in clubs and associations, it seems critical for organizations to attract more open-minded people. The same goes for conscientious persons, who also invest lots of effort into their voluntary work if they are active in a club or association. Furthermore, the study of moderating effects shows that the nonprofit sector, political actors, and employers can all draw important conclusions from our results. They should enable flexible working hours and the opportunity to reduce working hours for a certain period. Our findings show that agreeable persons, who are disposed to informally volunteer, will especially do so if they work part-time. Less working hours seem to provide them with enough time to care about their close environment as well as others living outside of their own household.

Despite its innovations, this study also has its limits, which should be addressed by future research. From a methodological perspective, we are unable to make any causal claims relying on cross-sectional data and applying conventional regression techniques. Experimental approaches as well as panel data could be promising ways to address this problem in future studies. Moreover, we are only able to test our theoretical expectations for one country using the Swiss Volunteering Survey. Replication studies for other countries and - at best-internationally comparative studies are necessary to examine whether our results can be generalized. Moreover, it is worthwhile thinking about further situational and contextual factors that may moderate the relationship between personality traits and volunteering. Dinesen et al. (2014) go in this direction by distinguishing between different types of associations. The differential effects of personality traits that they find are promising with regard to the study of contextual moderation. Finally, it might be worthwhile to move beyond the personality conception of the Five-Factor Model. Personality types based on the Big Five are one opportunity to account for the interplay of different traits, like Atkins, Hart, and Donnelly (2005) demonstrate. In sum, taking this work as a starting point, the floor is open for studies to dig deeper into the relationship between personality traits and different aspects of volunteering. 


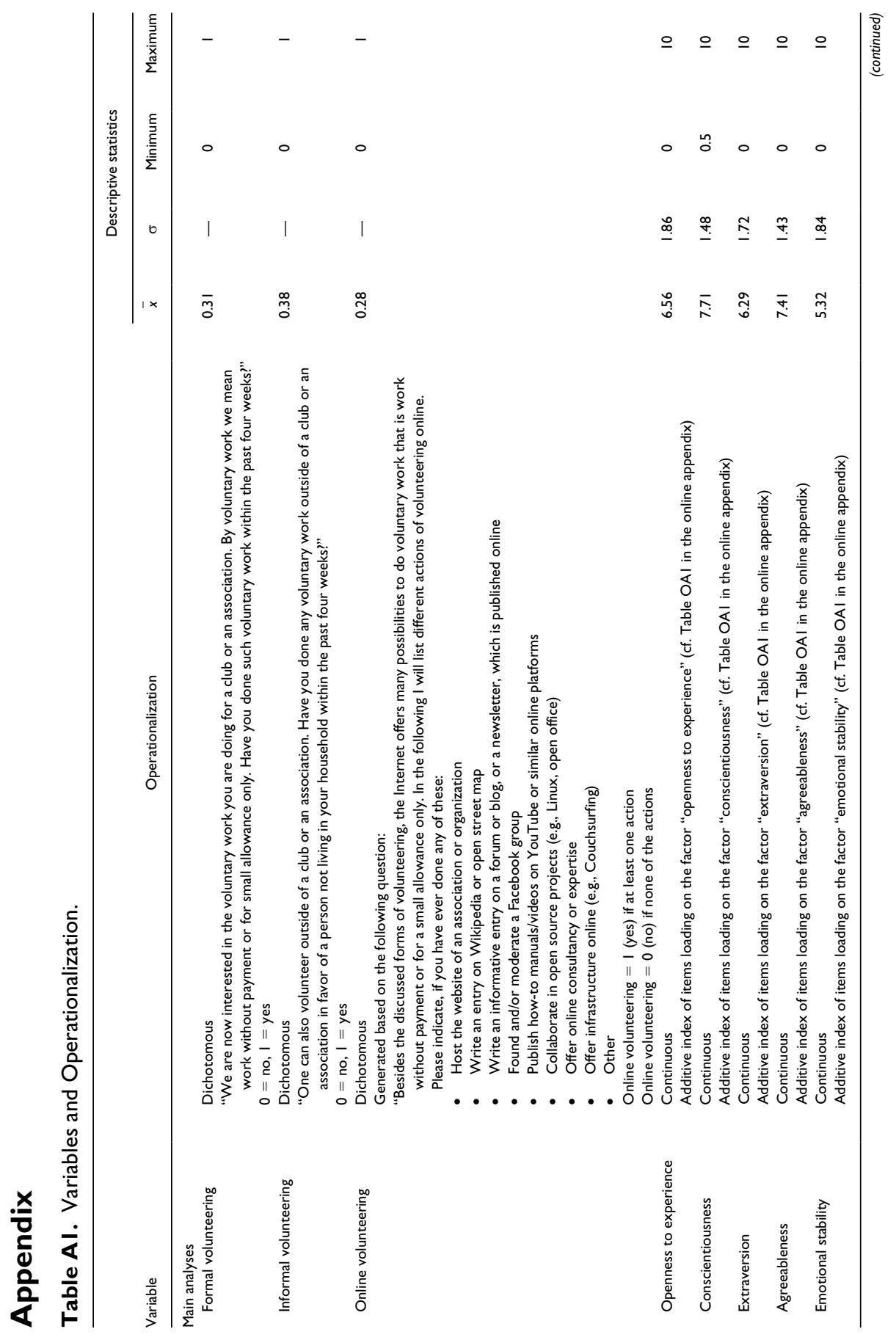




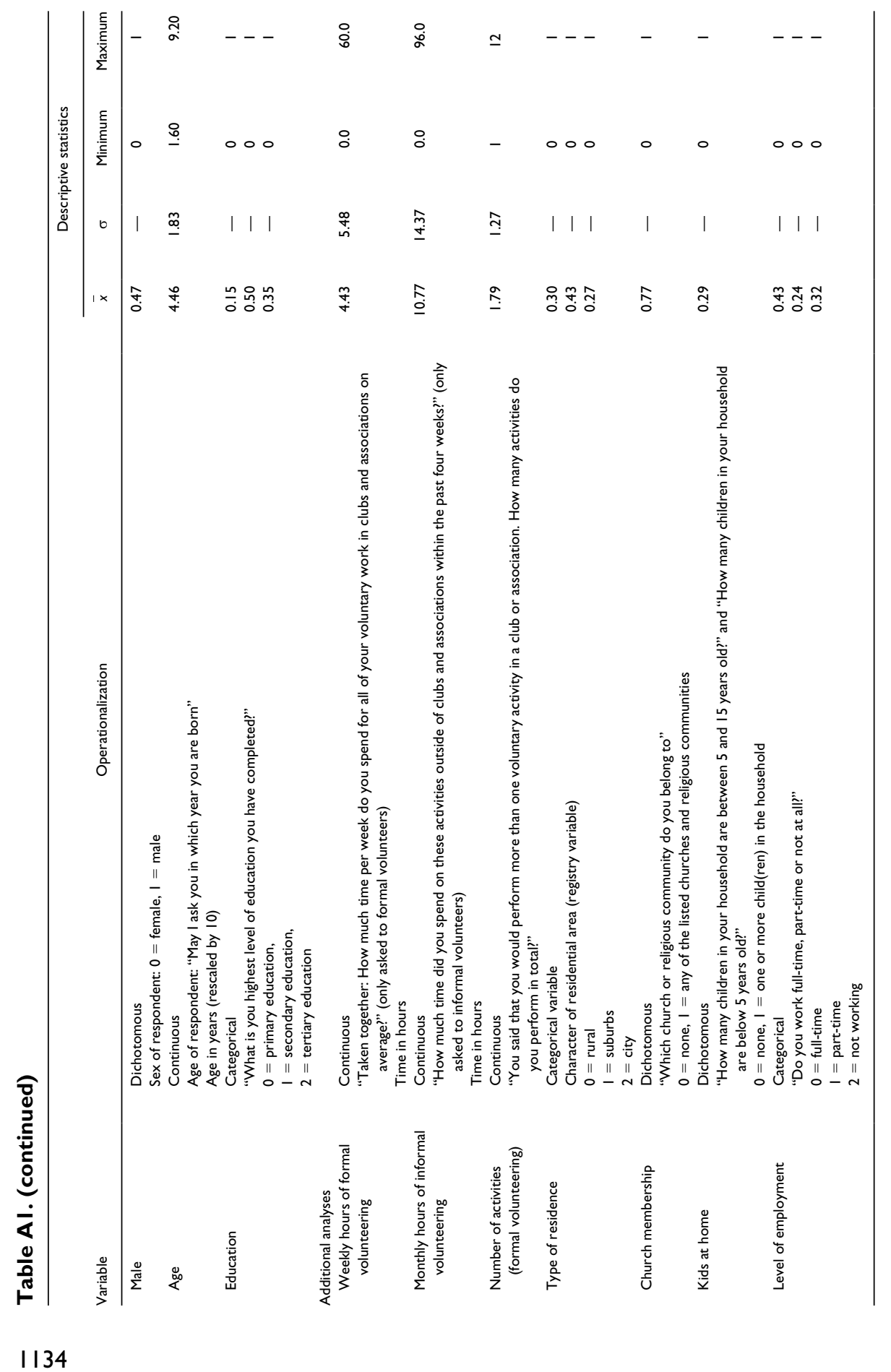


Table A2. Personality Traits and Volunteering in Switzerland (Logistic Regression Models).

\begin{tabular}{|c|c|c|c|}
\hline & MI & M2 & M3 \\
\hline & Formal & Informal & Online \\
\hline \multirow[t]{2}{*}{ Openness to experience } & $-0.05^{* *}$ & 0.03 & $0.17 * * *$ \\
\hline & $(0.02)$ & $(0.02)$ & $(0.03)$ \\
\hline \multirow[t]{2}{*}{ Conscientiousness } & -0.03 & -0.02 & $-0.11 * * *$ \\
\hline & $(0.02)$ & $(0.02)$ & $(0.02)$ \\
\hline \multirow[t]{2}{*}{ Extraversion } & $0.09 * * *$ & $0.06 * * *$ & $0.06 * *$ \\
\hline & $(0.02)$ & $(0.01)$ & $(0.02)$ \\
\hline \multirow[t]{2}{*}{ Agreeableness } & 0.03 & $0.05^{* *}$ & $-0.08^{* *}$ \\
\hline & $(0.02)$ & $(0.02)$ & $(0.03)$ \\
\hline \multirow[t]{2}{*}{ Emotional stability } & $0.09 * * *$ & 0.02 & $0.06 * *$ \\
\hline & $(0.01)$ & $(0.02)$ & $(0.02)$ \\
\hline \multirow[t]{2}{*}{ Male } & $0.14 * *$ & $-0.44 * * *$ & $0.62 * * *$ \\
\hline & $(0.05)$ & $(0.06)$ & $(0.06)$ \\
\hline \multirow{2}{*}{$\begin{array}{l}\text { Secondary education } \\
\text { (ref.: primary) }\end{array}$} & $0.48^{* * * *}$ & $0.39 * * *$ & 0.09 \\
\hline & $(0.09)$ & $(0.10)$ & $(0.09)$ \\
\hline \multirow{2}{*}{$\begin{array}{l}\text { Tertiary education } \\
\text { (ref.: primary) }\end{array}$} & $0.64 * * *$ & $0.41 * *$ & $0.7 I^{* * *}$ \\
\hline & $(0.09)$ & $(0.13)$ & $(0.13)$ \\
\hline \multirow[t]{2}{*}{ Age } & $0.21 *$ & $0.23 *$ & $-0.60 * * *$ \\
\hline & $(0.09)$ & $(0.09)$ & $(0.10)$ \\
\hline \multirow[t]{2}{*}{ Age $^{2}$} & -0.02 & $-0.02 *$ & $0.03 *$ \\
\hline & $(0.01)$ & $(0.01)$ & $(0.01)$ \\
\hline \multirow[t]{2}{*}{ Constant } & $-2.46 * * *$ & $-1.94 * * *$ & -0.05 \\
\hline & $(0.3 \mathrm{I})$ & $(0.24)$ & $(0.37)$ \\
\hline Pseudo $R^{2}$ & .02 & .02 & .09 \\
\hline Observations & 5,388 & 5,388 & $4,7 \mid 5$ \\
\hline
\end{tabular}

Note. Estimations based on the data set "Swiss Volunteering Survey 20I4"; logistic regression models with robust standard errors clustered by canton, standard errors in parentheses.

$*_{p}<.05 . *_{p}<.01$. ***p $<.001$. 
Table A3. Personality Traits and the Intensity of Volunteering in Switzerland (Negative Binomial Regression Models).

\begin{tabular}{|c|c|c|c|}
\hline & M4 & M5 & M6 \\
\hline & $\begin{array}{l}\text { Weekly hours of } \\
\text { formal volunteering }\end{array}$ & $\begin{array}{l}\text { Monthly hours of } \\
\text { informal volunteering }\end{array}$ & $\begin{array}{l}\text { Number of activities } \\
\text { (formal volunteering) }\end{array}$ \\
\hline \multirow[t]{2}{*}{ Openness to experience } & $0.07 * * *$ & 0.04 & 0.02 \\
\hline & $(0.01)$ & $(0.02)$ & $(0.01)$ \\
\hline \multirow[t]{2}{*}{ Conscientiousness } & $0.05 * *$ & 0.02 & -0.00 \\
\hline & $(0.02)$ & $(0.02)$ & $(0.01)$ \\
\hline \multirow[t]{2}{*}{ Extraversion } & 0.03 & -0.02 & 0.01 \\
\hline & $(0.02)$ & $(0.02)$ & $(0.01)$ \\
\hline \multirow[t]{2}{*}{ Agreeableness } & -0.04 & 0.02 & -0.01 \\
\hline & $(0.02)$ & $(0.02)$ & $(0.01)$ \\
\hline \multirow[t]{2}{*}{ Emotional stability } & -0.00 & 0.01 & $0.04 * *$ \\
\hline & $(0.02)$ & $(0.02)$ & $(0.01)$ \\
\hline \multirow[t]{2}{*}{ Male } & 0.13 & -0.11 & 0.08 \\
\hline & $(0.06)$ & $(0.06)$ & $(0.04)$ \\
\hline \multirow{2}{*}{$\begin{array}{l}\text { Secondary education } \\
\text { (ref.: primary) }\end{array}$} & 0.09 & 0.06 & $0.14 *$ \\
\hline & $(0.10)$ & $(0.10)$ & $(0.06)$ \\
\hline \multirow{2}{*}{$\begin{array}{l}\text { Tertiary education } \\
\text { (ref.: primary) }\end{array}$} & 0.17 & -0.04 & $0.25 * * *$ \\
\hline & $(0.1 I)$ & $(0.11)$ & $(0.04)$ \\
\hline \multirow[t]{2}{*}{ Age } & $-0.29 * * *$ & -0.13 & 0.09 \\
\hline & $(0.07)$ & $(0.10)$ & $(0.05)$ \\
\hline \multirow[t]{2}{*}{$\mathrm{Age}^{2}$} & $0.04 * * *$ & $0.03 * *$ & -0.01 \\
\hline & $(0.01)$ & $(0.01)$ & $(0.01)$ \\
\hline \multirow[t]{2}{*}{ Constant } & $0.82 * * *$ & $1.75^{* * *}$ & -0.16 \\
\hline & $(0.23)$ & $(0.24)$ & $(0.19)$ \\
\hline Pseudo $R^{2}$ & .02 & .01 & .01 \\
\hline Observations & 1,506 & 1,828 & $\mathrm{I}, 583$ \\
\hline
\end{tabular}

Note. Estimations based on the data set "Swiss Volunteering Survey 2014" (volunteers only); negative binomial regression models with robust standard errors clustered by canton, standard errors in parentheses.

$* p<.05 . * * p<.01 . * * * p<.001$. 
Table A4. The Relationship Between Conscientiousness and Volunteering in Switzerland Conditional on Social Network Indicators (Logistic Regression Models).

\begin{tabular}{|c|c|c|c|c|c|c|}
\hline & M7.I & M7.2 & M7.3 & M8.I & M8.2 & M8.3 \\
\hline & Formal & Informal & Online & Formal & Informal & Online \\
\hline \multirow[t]{2}{*}{ Openness to experience } & $-0.05^{* *}$ & 0.03 & $0.16 * * *$ & $-0.04 * *$ & 0.03 & $0.16 * * *$ \\
\hline & $(0.02)$ & $(0.02)$ & $(0.03)$ & $(0.02)$ & $(0.02)$ & $(0.03)$ \\
\hline \multirow[t]{2}{*}{ Conscientiousness } & -0.06 & 0.04 & $-0.09 *$ & -0.09 & -0.04 & -0.04 \\
\hline & $(0.03)$ & $(0.05)$ & $(0.04)$ & $(0.05)$ & $(0.03)$ & $(0.04)$ \\
\hline \multirow[t]{2}{*}{ *Suburbs } & 0.05 & $-0.11 *$ & 0.00 & & & \\
\hline & $(0.05)$ & $(0.05)$ & $(0.05)$ & & & \\
\hline *City & $\begin{array}{l}0.01 \\
(0.05)\end{array}$ & $\begin{array}{l}-0.04 \\
(0.06)\end{array}$ & $\begin{array}{l}-0.08 \\
(0.07)\end{array}$ & & & \\
\hline *Member of church & & & & $\begin{array}{c}0.06 \\
(0.06)\end{array}$ & $\begin{array}{c}0.02 \\
(0.04)\end{array}$ & $\begin{array}{r}-0.09 * \\
(0.04)\end{array}$ \\
\hline \multirow{2}{*}{$\begin{array}{l}\text { Suburbs } \\
\text { (ref.: rural) }\end{array}$} & $-0.76 *$ & 0.62 & -0.01 & & & \\
\hline & $(0.38)$ & $(0.35)$ & $(0.38)$ & & & \\
\hline \multirow{2}{*}{ City } & -0.61 & -0.04 & 0.69 & & & \\
\hline & $(0.34)$ & $(0.45)$ & $(0.53)$ & & & \\
\hline \multirow[t]{2}{*}{ Member of church } & & & & 0.17 & 0.05 & 0.55 \\
\hline & & & & $(0.46)$ & $(0.31)$ & $(0.32)$ \\
\hline \multirow[t]{2}{*}{ Extraversion } & $0.09 * * *$ & $0.06 * * *$ & $0.06 * *$ & $0.09 * * *$ & $0.06 * * *$ & $0.06 * *$ \\
\hline & $(0.02)$ & $(0.01)$ & $(0.02)$ & $(0.02)$ & $(0.01)$ & $(0.02)$ \\
\hline \multirow[t]{2}{*}{ Agreeableness } & 0.03 & $0.05^{* *}$ & $-0.08 * *$ & 0.01 & $0.04^{*}$ & $-0.08 * *$ \\
\hline & $(0.02)$ & $(0.02)$ & $(0.03)$ & $(0.02)$ & $(0.02)$ & $(0.03)$ \\
\hline \multirow[t]{2}{*}{ Emotional stability } & $0.09 * * *$ & 0.02 & $0.06 * *$ & $0.10 * * *$ & 0.02 & $0.06 * *$ \\
\hline & $(0.01)$ & $(0.02)$ & $(0.02)$ & $(0.01)$ & $(0.02)$ & $(0.02)$ \\
\hline \multirow[t]{2}{*}{ Male } & $0.14^{* *}$ & $-0.44 * * *$ & $0.63 * * *$ & $0.16^{* *}$ & $-0.44^{* * *}$ & $0.63^{* * *}$ \\
\hline & $(0.05)$ & $(0.06)$ & $(0.06)$ & $(0.05)$ & $(0.06)$ & $(0.06)$ \\
\hline \multirow{2}{*}{$\begin{array}{l}\text { Secondary education } \\
\text { (ref.: primary) }\end{array}$} & $0.50 * * *$ & $0.40 * * *$ & 0.09 & $0.52 * * *$ & $0.4 I^{* * *}$ & 0.11 \\
\hline & $(0.09)$ & $(0.10)$ & $(0.09)$ & $(0.10)$ & $(0.10)$ & $(0.08)$ \\
\hline \multirow{2}{*}{$\begin{array}{l}\text { Tertiary education } \\
\text { (ref.: primary) }\end{array}$} & $0.70 * * *$ & $0.45^{* * *}$ & $0.70 * * *$ & $0.73 * * *$ & $0.45^{* * *}$ & $0.7 I^{* * *}$ \\
\hline & $(0.10)$ & $(0.13)$ & $(0.14)$ & $(0.1 I)$ & $(0.12)$ & $(0.13)$ \\
\hline \multirow[t]{2}{*}{ Age } & 0.17 & $0.21^{*}$ & $-0.60 * * *$ & $0.22 *$ & $0.24 * *$ & $-0.63 * * *$ \\
\hline & $(0.09)$ & $(0.09)$ & $(0.10)$ & $(0.09)$ & $(0.09)$ & $(0.10)$ \\
\hline \multirow[t]{2}{*}{$\mathrm{Age}^{2}$} & -0.01 & $-0.02 *$ & $0.03^{*}$ & -0.02 & $-0.03 * *$ & $0.03^{* *}$ \\
\hline & $(0.01)$ & $(0.01)$ & $(0.01)$ & $(0.01)$ & $(0.01)$ & $(0.01)$ \\
\hline \multirow[t]{2}{*}{ Constant } & $-1.95^{* * *}$ & $-2.19 * * *$ & -0.24 & $-2.63 * * *$ & $-1.98 * * *$ & -0.41 \\
\hline & $(0.37)$ & $(0.42)$ & $(0.44)$ & $(0.5 I)$ & $(0.33)$ & $(0.52)$ \\
\hline Pseudo $R^{2}$ & .03 & .02 & .10 & .03 & .02 & .10 \\
\hline Observations & 5,388 & 5,388 & 4,715 & 5,307 & 5,307 & 4,639 \\
\hline
\end{tabular}

Note. Estimations based on the data set "Swiss Volunteering Survey 20I4"; logistic regression models with robust standard errors clustered by canton, standard errors in parentheses.

$*_{p}<.05 . * * p<.01 . * * * p<.001$. 
Table A5. The Relationship Between Agreeableness and Volunteering in Switzerland Conditional on Indicators of Time Constraints (Logistic Regression Models).

\begin{tabular}{|c|c|c|c|c|c|c|}
\hline & \multirow{2}{*}{$\frac{\text { M9.I }}{\text { Formal }}$} & \multirow{2}{*}{$\frac{\text { M9.2 }}{\text { Informal }}$} & \multirow{2}{*}{$\begin{array}{l}\text { M9.3 } \\
\text { Online }\end{array}$} & \multirow{2}{*}{$\frac{\text { MI0.I }}{\text { Formal }}$} & \multirow{2}{*}{$\frac{\text { MI0.2 }}{\text { Informal }}$} & \multirow{2}{*}{$\frac{\text { MI0.3 }}{\text { Online }}$} \\
\hline & & & & & & \\
\hline \multirow[t]{2}{*}{ Openness to experience } & $-0.05 * *$ & 0.03 & $0.16 * * *$ & $-0.05 * *$ & 0.02 & $0.17 * * *$ \\
\hline & $(0.02)$ & $(0.02)$ & $(0.03)$ & $(0.02)$ & $(0.02)$ & $(0.03)$ \\
\hline \multirow[t]{2}{*}{ Conscientiousness } & -0.03 & -0.02 & $-0.11 * * *$ & -0.03 & -0.02 & $-0.11 * * *$ \\
\hline & $(0.02)$ & $(0.02)$ & $(0.02)$ & $(0.02)$ & $(0.02)$ & $(0.02)$ \\
\hline \multirow[t]{2}{*}{ Extraversion } & $0.09 * * *$ & $0.06 * * *$ & $0.06 * *$ & $0.09 * * *$ & $0.06 * * *$ & $0.06 * *$ \\
\hline & $(0.02)$ & $(0.01)$ & $(0.02)$ & $(0.02)$ & $(0.01)$ & $(0.02)$ \\
\hline \multirow[t]{2}{*}{ Agreeableness } & 0.04 & $0.05^{*}$ & $-0.08 * *$ & 0.00 & 0.02 & $-0.10^{*}$ \\
\hline & $(0.02)$ & $(0.02)$ & $(0.03)$ & $(0.03)$ & $(0.02)$ & $(0.04)$ \\
\hline \multirow[t]{2}{*}{ *Kids at home } & -0.04 & -0.01 & -0.02 & & & \\
\hline & $(0.05)$ & $(0.04)$ & $(0.05)$ & & & \\
\hline *Part-time & & & & -0.02 & $0.09 *$ & 0.00 \\
\hline (ref.: full-time) & & & & $(0.06)$ & $(0.04)$ & $(0.04)$ \\
\hline *Not working & & & & 0.07 & 0.02 & 0.05 \\
\hline (ref.: full-time) & & & & $(0.04)$ & $(0.05)$ & $(0.05)$ \\
\hline \multirow{2}{*}{$\begin{array}{l}\text { Kids at home } \\
\qquad(I=\text { yes })\end{array}$} & 0.36 & 0.31 & -0.09 & & & \\
\hline & $(0.35)$ & $(0.29)$ & $(0.39)$ & & & \\
\hline \multirow{2}{*}{$\begin{array}{l}\text { Part-time } \\
\text { (ref.: full-time) }\end{array}$} & & & & 0.52 & -0.32 & 0.03 \\
\hline & & & & $(0.48)$ & $(0.28)$ & $(0.27)$ \\
\hline \multirow{2}{*}{$\begin{array}{l}\text { Not working } \\
\text { (ref.: full-time) }\end{array}$} & & & & -0.28 & -0.03 & -0.23 \\
\hline & & & & $(0.37)$ & $(0.35)$ & $(0.38)$ \\
\hline \multirow[t]{2}{*}{ Emotional stability } & $0.09 * * *$ & 0.02 & $0.06 * *$ & $0.09 * * *$ & 0.02 & $0.06 * *$ \\
\hline & $(0.01)$ & $(0.02)$ & $(0.02)$ & $(0.01)$ & $(0.02)$ & $(0.02)$ \\
\hline \multirow[t]{2}{*}{ Male } & $0.14^{* *}$ & $-0.44 * * *$ & $0.62 * * *$ & $0.25 * * *$ & $-0.34 * * *$ & $0.64 * * *$ \\
\hline & $(0.05)$ & $(0.06)$ & $(0.06)$ & $(0.06)$ & $(0.05)$ & $(0.05)$ \\
\hline \multirow{2}{*}{$\begin{array}{l}\text { Secondary education } \\
\text { (ref.: primary) }\end{array}$} & $0.49 * * *$ & $0.40^{* * * *}$ & 0.06 & $0.49 * * *$ & $0.35 * * *$ & 0.11 \\
\hline & $(0.09)$ & $(0.10)$ & $(0.09)$ & $(0.09)$ & $(0.10)$ & $(0.09)$ \\
\hline \multirow{2}{*}{$\begin{array}{l}\text { Tertiary education } \\
\text { (ref.: primary) }\end{array}$} & $0.65 * * *$ & $0.42 * * *$ & $0.67 * * *$ & $0.65 * * *$ & $0.39 * *$ & $0.72 * * *$ \\
\hline & $(0.09)$ & $(0.13)$ & $(0.14)$ & $(0.10)$ & $(0.12)$ & $(0.13)$ \\
\hline \multirow[t]{2}{*}{ Age } & $0.19 *$ & 0.18 & $-0.52 * * *$ & $0.23 *$ & $0.20 *$ & $-0.56 * * *$ \\
\hline & $(0.09)$ & $(0.10)$ & $(0.10)$ & $(0.09)$ & $(0.08)$ & $(0.10)$ \\
\hline \multirow[t]{2}{*}{$\mathrm{Age}^{2}$} & -0.02 & -0.02 & 0.02 & $-0.02 *$ & $-0.02^{*}$ & $0.02 *$ \\
\hline & $(0.01)$ & $(0.01)$ & $(0.01)$ & $(0.01)$ & $(0.01)$ & $(0.01)$ \\
\hline \multirow[t]{2}{*}{ Constant } & $-2.55 * * *$ & $-1.97 * * *$ & -0.12 & $-2.65 * * *$ & $-1.84 * * *$ & -0.07 \\
\hline & $(0.29)$ & $(0.26)$ & $(0.37)$ & $(0.4 I)$ & $(0.26)$ & $(0.43)$ \\
\hline Pseudo $R^{2}$ & .02 & .02 & .10 & .03 & .02 & .10 \\
\hline Observations & 5,388 & 5,388 & 4,715 & 5,353 & 5,353 & 4,680 \\
\hline
\end{tabular}

Note. Estimations based on the data set "Swiss Volunteering Survey 20I4"; logistic regression models with robust standard errors clustered by canton, standard errors in parentheses.

$* p<.05 .{ }^{* *} p<.01 .{ }^{* * *} p<.001$. 


\section{Acknowledgments}

An earlier version of this article was presented at ECPR General Conference in Montrèal 2015 and at the Political Psychology Conference in Amsterdam 2015. The author is grateful to the participants in the panels as well as to Markus Freitag, Birte Gundelach, Anita Manatschal, and the three anonymous reviewers for valuable comments and suggestions on previous versions of this article. Moreover, she acknowledges the excellent support of Goethe Research Academy for Early Career Researchers (GRADE) at Goethe University Frankfurt and Kevin Frac in proofreading this article.

\section{Declaration of Conflicting Interests}

The author(s) declared no potential conflicts of interest with respect to the research, authorship, and/or publication of this article.

\section{Funding}

The author(s) received no financial support for the research, authorship, and/or publication of this article.

\section{Notes}

1. Not all of these studies make use of the holistic Five-Factor Model of personality but consider specific facets of personality and not all of them use representative population samples. This further reduces their scope and informative value.

2. Some definitions of volunteering also include donating, which means voluntarily giving money to benefit others. This article is restricted to voluntary work and excludes donating, however.

3. The survey was financed by the Swiss Society for the Common Good (Schweizerische Gemeinnützige Gesellschaft [SGG]) in cooperation with the Migros Cultural Percentage and was supported by the Federal Statistical Office. It was conducted by the polling firm DemoSCOPE AG. For further information on the project, see http://www.sgg-ssup.ch/en/ volunteer-work-bulletin.html. For the data, see https://forsbase.unil.ch/

4. The figures visualizing the predicted probabilities were prepared using the plotplain scheme (Bischof, 2017).

\section{Supplemental Material}

Supplemental material for this article is available online.

\section{ORCID iD}

Kathrin Ackermann (iD https://orcid.org/0000-0002-8697-0184

\section{References}

Ackermann, K., \& Manatschal, A. (2018). Online volunteering as a means to overcome unequal participation? The profiles of online and offline volunteers compared. New Media \& Society, 20, 4453-4472.

Amichai-Hamburger, Y. (2008). Potential and promise of online volunteering. Computers in Human Behavior, 24, 544-562. 
Amichai-Hamburger, Y., \& Vinitzky, G. (2010). Social network use and personality. Computers in Human Behavior, 26, 1289-1295.

Amichai-Hamburger, Y., Wainapel, G., \& Fox, S. (2002). “On the Internet no one knows I'm an introvert": Extroversion, neuroticism, and internet interaction. CyberPsychology \& Behavior, 5, 125-128.

Amiel, T., \& Sargent, S. L. (2004). Individual differences in Internet usage motives. Computers in Human Behavior, 20, 711-726.

Atkins, R., Hart, D., \& Donnelly, T. M. (2005). The association of childhood personality type with volunteering during adolescence. Merrill-Palmer Quarterly, 51, 145-162.

Bekkers, R. (2005). Participation in voluntary associations: Relations with resources, personality, and political values. Political Psychology, 26, 439-454.

Bischof, D. (2017). New graphic schemes for Stata: Plotplain and plottig. The Stata Journal, 17, 748-759.

Carlo, G., Okun, M. A., Knight, G. P., \& de Guzman, M. R. T. (2005). The interplay of traits and motives on volunteering: Agreeableness, extraversion and prosocial value motivation. Personality and Individual Differences, 38, 1293-1305.

Carson, E. D. (1999). On defining and measuring volunteering in the United States and abroad. Law \& Contemporary Problems, 62(4), 67-71.

Correa, T., Hinsley, A. W., \& de Zúñiga, H. G. (2010). Who interacts on the Web? The intersection of users' personality and social media use. Computers in Human Behavior, 26, 247-253.

Dinesen, P. T., Nørgaard, A. S., \& Klemmensen, R. (2014). The civic personality: Personality and democratic citizenship. Political Studies, 62, 134-152.

Finkelstein, M. A., \& Brannick, M. T. (2007). Applying theories of institutional helping to informal volunteering: Motives, role identity, and prosocial personality. Social Behavior and Personality: An International Journal, 35, 101-114.

Finkelstein, M. A., Penner, L. A., \& Brannick, M. T. (2005). Motive, role identity, and prosocial personality as predictors of volunteer activity. Social Behavior and Personality: An International Journal, 33, 403-418.

Freitag, M., \& Ackermann, K. (2016). Direct democracy and institutional trust: Relationships and differences across personality traits. Political Psychology, 37, 707-723.

Freitag, M., \& Bauer, P. C. (2016). Personality traits and the propensity to trust friends and strangers. The Social Science Journal, 53, 467-476.

Funder, D. C. (2008). Persons, situations and person-situation interactions. In O. P. John, R. W. Robins, \& L. A. Pervin (Eds.), Handbook of personality: Theory and research (pp. 568580). New York, NY: Guilford Press.

Gerber, A. S., Huber, G. A., Doherty, D., \& Dowling, C. M. (2011). The Big Five personality traits in the political arena. Annual Review of Political Science, 14, 265-287.

Gerlitz,J.-Y.,\& Schupp,J.(2005).ZurErhebungderBig-Five-basierten Persönlichkeitsmerkmale im SOEP [On measuring the Big Five personality traits in the German Socio-Economic Panel (SOEP)] (DIW Research Notes 4). Retrieved from http://www.diw.de/documents/ publikationen/73/diw_01.c.43490.de/rn4.pdf

Gesthuizen, M., \& Scheepers, P. (2012). Educational differences in volunteering in crossnational perspective: Individual and contextual explanations. Nonprofit and Voluntary Sector Quarterly, 41, 58-81.

Hamburger, Y. A., \& Ben-Artzi, E. (2000). The relationship between extraversion and neuroticism and the different uses of the Internet. Computers in Human Behavior, 16, 441449. 
Jaccard, J., \& Jacoby, J. (2009). Theory construction and model-building skills: A practical guide for social scientists. New York, NY: Guilford Press.

John, O. P., Naumann, L. P., \& Soto, C. J. (2008). Paradigm shift to the integrative Big-Five trait taxonomy: History, measurement, and conceptual issues. In O. P. John, R. W. Robins, \& L. A. Pervin (Eds.), Handbook of personality: Theory and research (pp. 114-158). New York, NY: Guilford Press.

Jost, J. T., Nosek, B. A., \& Gosling, S. D. (2008). Ideology: Its resurgence in social, personality, and political psychology. Perspectives on Psychological Science, 3, 126-136.

Lee, Y., \& Brudney, J. L. (2012). Participation in formal and informal volunteering: Implications for volunteer recruitment. Nonprofit Management and Leadership, 23, 159-180.

Mark, G., \& Ganzach, Y. (2014). Personality and Internet usage: A large-scale representative study of young adults. Computers in Human Behavior, 36, 274-281.

McCrae, R. R., \& Costa, P. T. (2008). The five-factor theory of personality. In O. P. John, R. W. Robins, \& L. A. Pervin (Eds.), Handbook of personality: Theory and research (pp. 159181). New York, NY: Guilford Press.

Mondak, J. J. (2010). Personality and the foundations of political behavior. Cambridge, UK: Cambridge University Press.

Mukherjee, D. (2011). Participation of older adults in virtual volunteering: A qualitative analysis. Ageing International, 36, 253-266.

Musick, M. A., \& Wilson, J. (2008). Volunteers: A social profile. Bloomington: Indiana University Press.

Organisation for Economic Co-operation and Development. (2015). How's life? 2015: Measuring well-being. Paris, France: Author. doi:10.1787/how_life-2015-en

Okun, M. A., Pugliese, J., \& Rook, K. S. (2007). Unpacking the relation between extraversion and volunteering in later life: The role of social capital. Personality and Individual Differences, 42, 1467-1477.

Omoto, A. M., Snyder, M., \& Hackett, J. D. (2010). Personality and motivational antecedents of activism and civic engagement. Journal of Personality, 78, 1703-1734.

Orchard, L. J., \& Fullwood, C. (2010). Current perspectives on personality and Internet use. Social Science Computer Review, 28, 155-169.

Quintelier, E., \& Theocharis, Y. (2013). Online political engagement, Facebook, and personality traits. Social Science Computer Review, 31, 280-290.

Reimann, W. (2015). Freiwilligen-Monitor 2015. Methoden-Bericht [Swiss Volunteering Survey 2015. Methods Report]. Adligenswil, Switzerland: DemoSCOPE.

Russo, S., \& Amnå, E. (2016). The personality divide: Do personality traits differentially predict online political engagement? Social Science Computer Review, 34, 259-277.

Smith, D. H. (1994). Determinants of voluntary association participation and volunteering: A literature review. Nonprofit and Voluntary Sector Quarterly, 23, 243-263.

Stadelmann-Steffen, I., \& Freitag, M. (2010). Making civil society work: Models of democracy and their impact on civic engagement. Nonprofit and Voluntary Sector Quarterly, 40, 526-551.

Weinschenk, A. (2013). 'Cause you've got personality: Political participation and the tendency to join civic groups. SAGE Open, 3. doi:10.1177/2158244013508418

Wilson, J. (2000). Volunteering. Annual Review of Sociology, 26, 215-240.

Wilson, J. (2012). Volunteerism research: A review essay. Nonprofit and Voluntary Sector Quarterly, 41, 176-212. 


\section{Author Biography}

Kathrin Ackermann is an assistant professor at the Institute of Political Science at Heidelberg University. Before, she has been a postdoctoral researcher and lecturer at Goethe University, Frankfurt and a Swiss National Science Foundation (SNSF) Early Postdoc. Mobility Fellow at the University of Amsterdam. She has received her $\mathrm{PhD}$ in political science from the University of Bern. Her research on political psychology, political behavior, and social participation has been published, among others, in Political Psychology, Political Behavior, West European Politics, and New Media and Society. 